\title{
UVRAG Gene
}

National Cancer Institute

\section{Source}

National Cancer Institute. UVRAG Gene. NCI Thesaurus. Code C113221.

This gene is involved in both autophagy and DNA repair. 